\title{
The Impact of Structural Competence towards Speaking Competence of the Fourth Semester Students of English Department
}

\author{
Muhammad Nafi Annury \\ IAIN Walisongo Semarang \\ Jl. Walisongo 3-5 Semarang \\ nafiannury@gmail.com
}

\begin{abstract}
This paper tries to define any impact of structural competence towards speaking competence. In this research, the writer used descriptive co-relational method. It was used to describe whether there was an impact between two variables, i.e. structural competence $(X)$ as independent variable and speaking competence (Y) as dependent variable. The subject of study was the fourth semester students of English department of Tarbiyah Faculty IAIN Walisongo Semarang. After the data had been analyzed, it was found that there was significant impact of structural competence especially in appropriateness. It helped students to arrange words into sentences that they utter.
\end{abstract}

Keywords: Structural Competence, Speaking Competence

\begin{abstract}
Abstrak
Makalah ini bertujuan untuk mengetahui apakah ada dampak kemampuan berbicara terhadap kemampuan struktur berbahasa. Pada penelitian ini, penulis mengunakan metode deskriptif korelasi. Hal tersebut digunakan untuk mengetahui apakah ada dampak antara kedua varibel tersebut; kompetensi struktur bahasa (X) sebagai variabel yang
\end{abstract}


tidak berpengaruh dan kompetensi berbicara (Y) sebagai variabel yang terpengaruh. Subyek penelitian adalah mahasiswa semester empat Progdi Tadris Bahasa Inggris Fakultas Pendidikan IAIN Walisongo Semarang. Setelah dianalisa, ditemukan bahwa ada dampak yang signifikan terhadap kompetensi stuktur berbahasa terutama pada ketepatan pada penyusunan tuturan. Hal tersebut membantu mahasiswa dalam merangkai kata untuk menyusun kalimat yang mereka tuturkan.

Kata kunci: Kompetensi struktur berbahasa, Kompetensi berbicara

\section{Introduction}

English is an international language which used all over the world. Many people learn to master it because many aspects in modern life cannot be separated from English. Nowadays we can find everything is written in English. As one of the aspects of globalization, English is now considered more and more important.

English is spoken throughout the world and in most of multilingual societies; it has been adopted as the official language of law, administration, commerce, and education. In nearly every country in the world, English is taught in school as the major second language (Gathered, 1996: VI)

There are four skills in mastering English, they are speaking, listening, reading and writing. Speaking is considered primary (Finocchiaro, 1973:3) because people learn to speak their native language several years before they learn to read and to write it. People judge one's English competence through his speaking. If a student can speak English well, it indicates that he masters English.

There are some elements of language such as vocabulary, structure, pronunciation, spelling, etc. Structure, as one of the elements of 
English is very important in language teaching. It is the system of language (Byrne, 1979), how the language is organized and used in communication. We can understand the language if we know its structure.

Some other time, the writer finds some students who understand structure, but in fact, they seem have difficulties in English especially in their speaking class. For instances: students still making mistakes on defining Present and Simple Past Tense. They often do this cause they are not realized when they have to change some activities which done in the past, therefore, they speak it in the Present Tense. It means that students knowledge of structural competence which they have do not support them much.

Since structure is a fundamental in mastering English, and speaking is considered primary, the writer formulates a problem. The writer tries to define any impact of structural competence towards speaking competence of fourth semester students of English department of Tarbiyah Faculty IAIN Walisongo Semarang in the academic year of 2010/2011.

\section{Nature of structure}

As one of the elements of language, structure is very important learning, since it is the basic framework to master the production and comprehension of the typical sentences of the language. When people communicate with others, they may utter a word or some words to convey their ideas, thought or feelings. The words, which are form then, are called sentence. The sentence can be defined as a group of words joined together by grammatical agreement (relating device) and which, 
not grammatically dependent upon any other groups, are complete in themselves (Fries, 1952:20). Quirk and Greenbaun (1976:12) stated that a sentence may alternatively be seen as compromising five units called of sentence; structure, i.e: subject, verb, complement, object, and adverbial abbreviated as $\mathrm{S}, \mathrm{V}, \mathrm{C}, \mathrm{O}, \mathrm{A}$.

a. Elements of Sentence

The elements are simply explained below:

1. Subject is a noun or pronoun that comes before the verb in an ordinary affirmative sentence. It usually says (in an active sentence) who or what does the action that verb refers to.

2. Verb is word, which is used with a subject to form the basics of a clause. Most verbs refer to actions or states.

3. Object is a noun or pronoun that normally comes after the verb (in active sentence). There are two kind of object:

a) Direct Object

It refers to a person or thing affected by the action of the verb.

b) Indirect Object

It usually refers to a person who receives the direct object.

1) Adverbial is a group of words that does the same job as an adverb phrase or adverb clause.

2) Complement is a part of sentence that gives more information about subject (after be, seem and the same after verbs) or in some structures, about object (Swan: 1980).

b. The Sentence Classification

Sentence is divided according to their structure into class simple, compound and complex sentence. 


\section{Simple sentence}

A simple sentence is a group of words, which express a single independent thought or contains one independent clause only. Quirk and Greenbaun (1976: 191) divided simple sentence into four major syntactic classes, whose use correlates with different communicative functions:

a) Statements are sentences in which the subject is always presented and generally precedes the verb, example: A student comes to the class.

b) Questions are sentences marked one by one or more of these criteria:

1) The placing of the operator immediately in front of the subject, example: Does a student come to the class?

2) The initial positioning of an interrogative or wh- elements, example: Who comes to the class?

3) Rising intonation, example: A student comes to the class?

c) Commands are sentences, which normally have no overt grammatical subject and whose; verb is in the imperative, example: Come on the class!

d) Exclamations are sentences which have an initial phrase introduced by what or how, without inversion subject and operator; example: What a diligent student!

2. Compound sentence

Compound sentence is a sentence that combined from two or more simple sentences (main clause) joined coordinately by 
punctuation alone, by coordinate conjunctions or by conjunctive adverbs.

a) Joined by punctuation alone

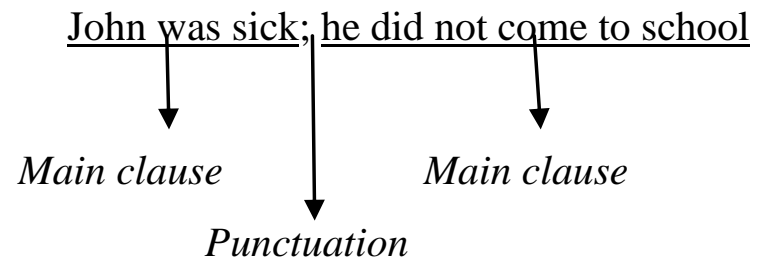

b) Joined by coordinative conjunction; and, but, or.

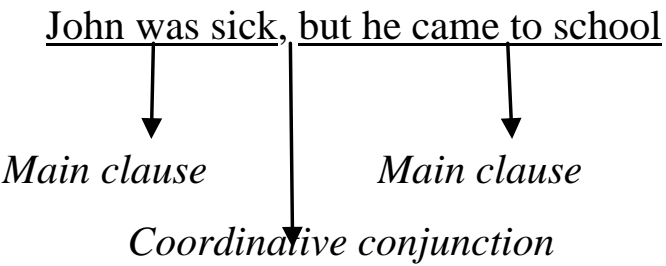

c) Joined by conjunctive adverb; moreover, in addition, otherwise, however, nevertheless, therefore, etc.

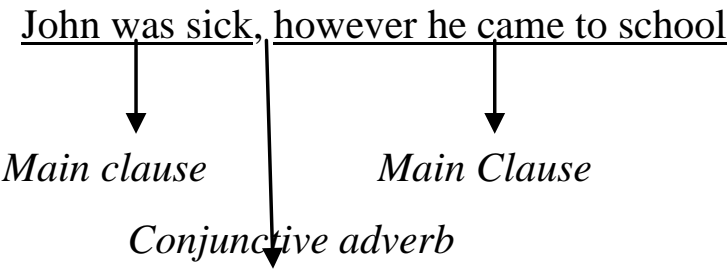

3. Complex sentence

A complex sentence is a sentence that consisting of one main clause and one or more subordinate clauses.

For example: They watch the television whenever they like

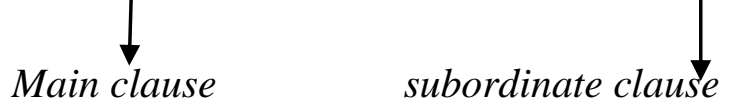




\section{Compound complex sentence}

Compound complex sentence is a sentence that consists of two or more main clauses and one more subordinate clauses. For example: since I had seen her the day before, I knew that he was unhappy, but I did not guess that he would give up this plan.

\section{Language skills}

Anyone who uses languages well has a number of different abilities. He/she may read books, write letters, speak on the telephone, listen to the radio, and so on. Generally, we can identify four major skills such as; listening, speaking, reading and writing (Hammer, 1978: 16). Those skills are classified into productive and receptive skills. Speaking and writing are productive skills and involve some kinds of production on the part of the language user. Listening and reading understanding belong to receptive skills and involve the language user is receiving written or spoken language.

When two people carry out a conversation, they very often use a combination of skills, for example speaking and listening skills. As we know that speaking is a part of language skills which should be mastered by students. As stated in the 2006 national curriculum states that students should master the four language skills besides speaking, there are: listening, writing and reading. Therefore, English still becomes one of the compulsory subjects which have been afraid by students.

\section{Nature of communication}

When two people are in talking to each other, we can fairly be sure that are so far a certain reason. The reasons they may have are as follows: 
a. They want to say something. "Want" is used here in general way to suggest that speakers make definite decisions to address other people. Speaking may be forced upon them but we can call still say they feel the need to speak, otherwise they would keep silent.

b. They have some comunicative purposes. Speakers say things because they want something to happen as a result of what they say. They may want to give information or express their ideas. They may decide to be rude or flatter, to agree communicative purpose, or succeed in conveying the message and the effect they want it to have.

c. They select from their language store. Speakers have an infinitive capacity to create new sentences (especially if they are native speakers). In order to achieve their communicative purpose, they will select the language they think is appropriate for this purpose.

d. They want to listen to "something". Once again "want" is used in general way. But the listeners in order to understand what they are listening to they must have some desire to do so.

e. They are interested in the communicative purpose of what is being said. In general people listen to because they want to find out what the speaker is going to say - in other words what ideas they are conveying, and what effect they wish the communication to have.

f. The process a variety of languages. Although the listener may have a good idea of what the speaker is going to say next in general terms, he has to be prepared to process a great variety of life grammar and vocabulary to understand exactly what is being said.

As we see from the explanation above that oral communication is a two-way process between speaker and listener, involving the productive skill of speaking and receptive skill of understanding. Both 
speaker and listener have a positive function to perform. The speaker has encode the message to be conveyed in appropriate language, while the listener has to decode (or interpret) the message. The message itself, in normal speech, usually contains a great deal of "information" which is redundant. At the some other time, the listener is helped by prosodic feature, such as stress and intonation, which accompany the spoken utterances and form part of its meaning, hence, by facial and body movement.

\section{Oral production}

The main goal in teaching the productive skill of speaking is oral fluency that is the ability to express oneself intelligibility, reasonably, accurately and without undue hesitation. To attain this goal, the students will be brought from the stage where they merely imitate a model or respond to cues to the point where they can use the language to express their own ideas. Two complementary levels of training will therefore be required practice in the manipulation of the six elements of the language (principally the use of grammatical patterns and lexical terms) and practice in the expression of personal meaning. For the purpose the teacher cannot depend on written texts as basic for oral practice. Audio visual aids, on the other hand, provide at all levels a powerful way of stimulating and developing oral ability without resource to the written language.

\section{Interdependence of the oral skills in communication}

Although in the class practice it is often necessary to concentrate at certain times developing one of the oral skills more than others, we 
should not lose sight of the fact that oral comunication is two-ways process between speaker and listener. Thus, the speaker does not always imitate: he also responds to what he has heard, while the listener does not always remain silent: he is normally expected to make some sort of response. In classroom, therefore, appropriate provision has to be made to see that the two oral skills are integrated through situations, which permit and encourage authentic comunication.

\section{Intelligibility}

Intelligibility is usually defined in phonological sound such as /i:/ and /i/. At a level of basic understanding this aspect of intelligibility is unquestionably important but for the purpose of oral fluency, the terms need to be able to communicate effectively, the leaners need an adequate matery of grammar and vocabulary as well as phonology. In the arrea of grammar, learners should not be expected to master grammatical items simply because the exist in the language, but not only those essential for communication.

\section{Oral ability and motivation}

The development of oral ability is a good source of motivation for most learners who normally much concern to be able to speak and uderstand a foreign language. Satisfaction at being able to say a small number of sentences after a few lesson must be sustained by demonstrating to the students that they can say progresively more and more through the language as the course continues. Motivation can often be improved in large classes by placing greater emphasis on the receptive skill of listening. This has the additional advantage of getting the students 
accustomed to understanding the language without reference to a written text as well as providing opportunities the meaningful repetition of known.

\section{Communicative competence}

From the baby onwards, everybody starts to learn how to communicate effectively and how to respond to other people's communications. Some people are better at communicating than others, but common people learn to communicate through language.

One of the importance factors in context is the nature of the participants. The age, sex, social status and educational level of the speaker and listener, all affect that the mode of expression used.

The next two factors are closely connected with each other. They are actual situation in which the language occurs and the kind of contact between the participants. The importance of the situation itself has always been recognized, and it is heavily emphasized in situational language courses, as well as in travelers; phrase books, where it becomes clear that the language varies according to whether one is shopping, or asking direction, or booking at the hotel and restaurant. Depending on the situation, the contact between the participants could either in speech or in writing, and at any points on the range of proximity, i.e. face to face, not face-to-face (two ways contact by telephone or correspondence), or one way contact (radio, TV, advertisement, notice). Simply by observing the choice of expression, one can postulate circumstances' in which one or the other would be likely to be written rather than spoken, used in one place rather than another. 
Another parameter is the nature of the subject matter or topic or field of discourse. Its influence has been recognized for extreme of English Special Purposes such as technical usage, international aviation English, legal terminology, etc.

\section{Mod and purpose}

The way people communicate, as well as what they communicate is a matter of choice. It is restricted by the conventions of the speech community and the language itself. The external factors governing usage play their part in decreeing what is appropriate to different circumstances.

A speaker is free to choose the mood as he wishes to convey as well as what he wants to say, he is constrained by the available resources of the language to fulfill his aims. That's why he must select not only a correct expression but one that is appropriate to his intentions.

Regarding the function of communication, there are five general functions, which can usefully be isolated: personal. The speaker will be open to interpret as polite, aggressive, in a hurry, angry, pleased, etc., according to how he speaks Directive. The speaker attempts to control of influence the listener in some ways. Establishing relationship: the speakers establish and maintain contact the listener, often by speaking in ritualized way in which what is said is not as important as the fact that is said is not as important as information to the listener. Enjoyment: the speaker is using language for its own 'sake' in poetry, rhymes, songs, etc (Corder, 1973:42-9). 


\section{Basic assumption}

Structure is the rule of language that enables speakers to express and organized their ideas through sentences or utterances or in the other words to carry out a communication with others. Therefore, students must understand the English structure in order to speak English. Without understanding its structure, it is very hard to get the meaning of the message conveyed.

\section{Research Method}

In this study the writer used descriptive co-relational method. It was used to describe whether there was impact between two variables, i.e. structural competence $(\mathrm{X})$ as independent variable and speaking competence $(\mathrm{Y})$ as dependent variable.

The population of this research was the fourth semester students of English Department Tarbiyah Faculty IAIN Walisongo Semarang in the academic year of $2011 / 2012$. The number of the population was sixty (60) students. The sample was taken from the all students of fourth semester because the total number of population was less than 100 subjects.

In collecting the data of this research, the writer used test as the instrument. There were two kinds of tests. The structure oral test was used to measure students' competence in structure. The other test, oral test was used to collect data of students' speaking competence. The tests had been carried out at June 27th 2011 and June 29th 2011.

1. Structure test

Structure test of 40 items, and the test contains multiple choice ones. The test is compiled from TOEFL. The consideration of 
compiling it is that TOEFL, is a standardized test and admitted by people to measure one's English competence.

Table 1

The content of structure test

\begin{tabular}{|c|l|l|}
\hline No & \multicolumn{1}{|c|}{ Materials } & Item Numbers \\
\hline 1 & Duration: since & 1 \\
\hline 2 & Used to & 2 \\
\hline 3 & Numerical order the & 3,4 \\
\hline 4 & Not only ............. but also & 5 \\
\hline 5 & Causative have, make & $6,7,8$ \\
\hline 6 & Conditional type I & 9,10 \\
\hline 7 & Conditional type II & 11 \\
\hline 8 & Had better & 12 \\
\hline 9 & Paralel structure & 13,14 \\
\hline 10 & Anticipatory II & 16 \\
\hline 11 & Uncountable noun & 17 \\
\hline 12 & Countable noun & 18 \\
\hline 13 & Degree comparison & 19,20 \\
\hline 14 & Adjective clause & 22,23 \\
\hline 15 & Would rather & 24 \\
\hline 16 & Passive voice & 25 \\
\hline 17 & Indirect question & 26,27 \\
\hline 18 & Infinitive to & 28,29 \\
\hline 19 & Verb + ing form & 30,31 \\
\hline 20 & Verbal modifier - ing form & 32 \\
\hline 21 & Either; neither & 33,34 \\
\hline 22 & Clause & 35,36 \\
\hline 23 & Because & 37 \\
\hline 24 & Reflexive pronoun & 38 \\
\hline 25 & Because of & 39 \\
\hline 26 & Adverb & 40 \\
\hline & & \\
\hline
\end{tabular}

2. Oral test

Underhill (1987: 44-81) states there are twenty techniques to test speaking skill, i.e.: discussion oral report, learner-learner joint 
discussion, role-play, interview, learner-learner description and recreation, form filling, making appropriate responses, questions answer, reading blank dialogue, using picture, giving description, i.e.: tell story or text from aural stimuli, reading aloud, translating/interpreting sentence completion from aural or written stimulus, sentence correction, sentence transformation and sentence repetition. From those techniques, the writer taught that using picture was effective and the most efficient to conduct the test. The components of language proficiency used are:

a. Fluency

It refers to one's ability to speak a language smoothly and easily

b. Grammar

It concerns with one's ability to organize words into sentences grammatically correct and to measure one's ability in applying grammatical rule as well.

c. Vocabulary

This item is designed to measure one's skill to remember or retake any words from his memory.

d. Pronunciation

It measures one's ability to pronounce English sounds correctly, includes its aspects like stress, intonation, etc.

3. Scoring systems

a. Scoring of structure test

The structure test consists of 40 items and all are multiple choice. The score of each number is one for the right one. So we can get a maximum score around 40 . 
b. Scoring of oral test

As mentioned above that the test type used is using picure.

There are seven pictures that must be retold by the students for about ten minutes. The components of language proficiency, grammar, vocabulary and pronounciation. The maximum score of each is 20 , thus the total score is 80 .

Table 2

The Speaking Score

\begin{tabular}{|c|l|c|c|}
\hline No & \multicolumn{1}{|c|}{ Language aspects } & Number of items & Score \\
\hline 1 & Fluency & $5 \times 4$ & 20 \\
2 & Grammar & $5 \times 4$ & 20 \\
3 & Vocabulary & $5 \times 4$ & 20 \\
4 & Pronounciation & $5 \times 4$ & 20 \\
& Total & & 80 \\
\hline
\end{tabular}

To make it easier, the writer gives criteria for each components and it is applied by score $1-5$. The criteria are mentioned below:

1. Fluency

5: speak smoothly and easily without any grooving

4 : speak with only accational hesitation

3: frequently have to think first before speak but enable to continue to speak

2: often stop speaking

1: say a word then stop speaking

2. Grammar

5: the sentences are all grammatically correct

4: making mistakes but not destroy the meaning 
3: making mistakes and destroy the meaning

2: the utterances are difficult to be understood

1: the speech cannot be understood at all

3. Vocabulary

5: using appropriate vocabulary

4: using some innapropriate words

3: frequently using innapropriate

2: having very limited vocabulary

1: stop speaking at all

4. Pronounciation

5: Pronounce all words correctly

4: understandable although having certain accent

3: paying attention a lot of and making understanding

2: often making misprouncing

1: the speech is not understandable

\section{Discussion}

\section{Students' structural competence}

1. Classical structural competence

In measuring the classical structural competence is $50.4 \%$. Thus the classical structural competence is $50.4 \%$. It can be said that the students structural competence is fair.

To know the precentage of students' competence, Arikunto (1991: 67) suggested five categories the students' competence as follows:

a. Very good: if $81-100 \%$ the answer are correct

b. Good: if $61-80 \%$ of the answer are correct 

c. Fair: if $41-60 \%$ of the answer are correct
d. Bad: if $21-60 \%$ of the answer are correct
e. Very bad: if $0-20 \%$ of the answer are correct

2. Frequency distribution of structural competence

The computation of frequency distribution of students' structural competence is as follows:

Table 3

The Length of Class Interval

\begin{tabular}{|c|l|l|l|}
\hline Class interval & \multicolumn{1}{|c|}{ Fi Xi } & \multicolumn{1}{|c|}{ Fixi } \\
\hline $30-32$ & 3 & 31 & 93 \\
\hline $27-29$ & 5 & 28 & 140 \\
\hline $24-26$ & 8 & 25 & 200 \\
\hline $21-23$ & 12 & 22 & 264 \\
\hline $18-20$ & 16 & 19 & 304 \\
\hline $15-17$ & 10 & 19 & 160 \\
\hline Des -14 & 6 & 13 & 78 \\
\hline Total & 50 & 157 & 1239 \\
\hline
\end{tabular}

a. Determining the range of scores by substracting the highest score by lowest score. The range of students' structure is the highest score: 31 , and the lowest score: 12 . The range is 19 .

b. The number of class interval by using the formula $1+3.3 \log 50$. The result is 6.606. so the number of class internal is 7 .

c. Length of class interval is 2.71

In this case the length of class interval used is 3 
3. Measure of central tendency of structural competence

Table 4

The Structural Competence

\begin{tabular}{|l|l|l|}
\hline Mean & Median & Mode \\
\hline 20.31 & 20.125 & 19.3 \\
\hline
\end{tabular}

a. The mean of students' structural competence has been compurized by frequency distribution is 20.31

b. Thus the median of structural competence is 20,125

c. Mode 19.3

Students' speaking competence

Table 5

The Students' speaking Competence

\begin{tabular}{|l|l|l|l|}
\hline Class interval & $\mathrm{Fi}$ & $\mathrm{Yi}$ & $\mathrm{Fi} . \mathrm{Yi}$ \\
\hline $72-74$ & 3 & 73 & 219 \\
$69-71$ & 9 & 70 & 630 \\
$66-68$ & 13 & 67 & 871 \\
$63-65$ & 3 & 64 & 192 \\
$60-62$ & 15 & 61 & 915 \\
$57-59$ & 5 & 58 & 290 \\
$54-56$ & 5 & 55 & 275 \\
$51-53$ & 5 & 52 & 260 \\
Total & 58 & 62 & 3652 \\
\hline
\end{tabular}

1. Classical speaking competence is $80.125 \%$

Thus the classical speaking competence is $80.125 \%$. We can categorize that the classical speaking competence is good. It can be seen in Arikunto (1991: 67) in the previous pages. 
2. Frequency distribution

The computation of frequency distribution of students speaking competence is as follows:

a. The range of students' speaking competence is, the highest score: 73 , and the lowest score: 51 . The range is 22 .

b. The number of class interva by using the formula: $1+3.3 \log 50$, the result is 6.606. So, the number of class interval is 7

c. The length of class interval $(\mathrm{P})$ is 3.14

In this case the length of class interval used is 3

3. Measure of central tendency of speaking competence a. The mean is 59,868

Thus the main of speaking competence is 59.868

b. Median

Thus, the median of speaking competence is 66,4

c. Mode

The mode of speaking competence is 66.357

\section{Product moment correlation}

The computation of product moment correlation coefficient is done after we find the values of $\mathrm{N}, \sum \mathrm{X}, \sum \mathrm{Y}, \sum \mathrm{X}^{2}, \sum \mathrm{Y}^{2}$, and $\sum \mathrm{XY}$ score. The result of computation using Pearson's formula is 0.990

Table 6

The Respondents

\begin{tabular}{|c|c|c|c|c|c|}
\hline Respondents & $\mathrm{R}$ & $\mathrm{Y}$ & $\mathrm{X}^{\wedge} 2$ & $\mathrm{Y}^{\wedge} 2$ & $\mathrm{XY}$ \\
\hline $\mathrm{R} 1$ & 20 & 60 & 400 & 3600 & 1200 \\
\hline $\mathrm{R} 2$ & 16 & 56 & 256 & 3136 & 896 \\
\hline $\mathrm{R} 3$ & 19 & 59 & 361 & 3481 & 1121 \\
\hline
\end{tabular}




\begin{tabular}{|c|c|c|c|c|c|} 
R4 & 23 & 63 & 529 & 3969 & 1449 \\
\hline R5 & 19 & 59 & 361 & 3481 & 1121 \\
\hline R6 & 17 & 57 & 289 & 3249 & 969 \\
\hline R7 & 17 & 57 & 289 & 3249 & 969 \\
\hline R8 & 18 & 58 & 324 & 3364 & 1044 \\
\hline R9 & 18 & 58 & 324 & 3364 & 1044 \\
\hline R10 & 18 & 58 & 324 & 3364 & 1044 \\
\hline R11 & 22 & 62 & 484 & 3844 & 1364 \\
\hline R12 & 20 & 60 & 400 & 3600 & 1200 \\
\hline R13 & 24 & 64 & 576 & 4096 & 1536 \\
\hline R14 & 20 & 60 & 400 & 3600 & 1200 \\
\hline R15 & 19 & 59 & 361 & 3481 & 1121 \\
\hline R16 & 21 & 61 & 441 & 3721 & 1281 \\
\hline R17 & 27 & 67 & 729 & 4489 & 1809 \\
\hline R18 & 26 & 66 & 676 & 4356 & 1716 \\
\hline R19 & 24 & 64 & 576 & 4096 & 1536 \\
\hline R20 & 13 & 53 & 169 & 2809 & 689 \\
\hline R21 & 15 & 55 & 225 & 3025 & 825 \\
\hline R22 & 23 & 63 & 529 & 3969 & 1449 \\
\hline R23 & 19 & 59 & 361 & 3481 & 1121 \\
\hline R24 & 21 & 61 & 441 & 3721 & 1281 \\
\hline R25 & 15 & 55 & 225 & 3025 & 825 \\
\hline R26 & 26 & 66 & 676 & 4356 & 1716 \\
\hline R27 & 24 & 64 & 576 & 4096 & 1536 \\
\hline R28 & 20 & 60 & 400 & 3600 & 1200 \\
\hline R29 & 20 & 60 & 400 & 3600 & 1200 \\
\hline R30 & 20 & 60 & 400 & 3600 & 1200 \\
\hline R31 & 22 & 62 & 484 & 3844 & 1364 \\
\hline R32 & 21 & 61 & 441 & 3721 & 1281 \\
\hline R33 & 19 & 59 & 361 & 3481 & 1121 \\
\hline R34 & 21 & 61 & 441 & 3721 & 1281 \\
\hline R35 & 19 & 59 & 361 & 3481 & 1121 \\
\hline R36 & 23 & 63 & 529 & 3969 & 1449 \\
\hline R37 & 16 & 56 & 256 & 3136 & 896 \\
\hline R38 & 23 & 63 & 529 & 3969 & 1449 \\
\hline R39 & 18 & 58 & 324 & 3364 & 1044 \\
\hline R40 & 20 & 60 & 400 & 3600 & 1200 \\
\hline R41 & 19 & 59 & 361 & 3481 & 1121 \\
\hline & & & & & \\
\hline
\end{tabular}




\begin{tabular}{|c|c|c|c|c|c|}
\hline R42 & 20 & 60 & 400 & 3600 & 1200 \\
\hline R43 & 20 & 60 & 400 & 3600 & 1200 \\
\hline R44 & 23 & 63 & 529 & 3969 & 1449 \\
\hline R45 & 26 & 66 & 676 & 4356 & 1716 \\
\hline R46 & 19 & 59 & 361 & 3481 & 1121 \\
\hline R47 & 22 & 62 & 484 & 3844 & 1364 \\
\hline R48 & 21 & 61 & 441 & 3721 & 1281 \\
\hline R49 & 18 & 58 & 324 & 3364 & 1044 \\
\hline R50 & 21 & 61 & 441 & 3721 & 1281 \\
\hline R51 & 22 & 62 & 484 & 3844 & 1364 \\
\hline R52 & 21 & 61 & 441 & 3721 & 1281 \\
\hline R53 & 21 & 61 & 441 & 3721 & 1281 \\
\hline R54 & 20 & 60 & 400 & 3600 & 1200 \\
\hline R55 & 24 & 64 & 576 & 4096 & 1536 \\
\hline R56 & 17 & 57 & 289 & 3249 & 969 \\
\hline R57 & 25 & 65 & 625 & 4225 & 1625 \\
\hline R58 & 20 & 60 & 400 & 3600 & 1200 \\
\hline R59 & 15 & 55 & 225 & 3025 & 825 \\
\hline R60 & 20 & 60 & 400 & 3600 & 1200 \\
\hline R61 & 20 & 60 & 400 & 3600 & 1200 \\
\hline & 1240 & 3680 & 25726 & 222526 & 75326 \\
\hline
\end{tabular}

From this table above we know that the computation of product moment correlation coefficient is done after we find the values of $\mathrm{N}, \sum \mathrm{X}$, $\sum \mathrm{Y}, \sum \mathrm{X} 2, \sum \mathrm{Y} 2$, and $\sum \mathrm{XY}$ score. The result of computation using Pearson's formula is 0.0990 .

\section{Conclusion}

The classical structural competence of fourth semester students of English Department of Tarbiyah Faculty IAIN Walisongo Semarang is $50.4 \%$. It can be catgorized in fair level and the mean of structural competence is 20.125. The classical speaking competence of fourth semester students of English Department of Tarbiyah Faculty IAIN 
Walisongo Semarang is $59.868 \%$ and it is good category. The mean of speaking competence is 63.76. It occurs because structure is a small element in speaking besides vocabulary, pronounciation, and fluency that work together. The result showed that there was significant impact of structural competence especially in appropriateness because they are able to arrange words into sentences when they utter.

\section{References}

Arikunto, Suharsimi. 2006. Prosedur Penelitian: Suatu Pendekatan Praktik. Jakarta: PT. Rineka Cipta.

Byrne, James. 1973. Principles of Language Learning and Teaching. New York: Addison Wesley Longman

Corder, Dale. 1973. How To Develop Self-Confidence And Influence People by Public Speaking. London: Vermilion.

Fries, CC. 1952. Speech Communication Made Simple. New York: Addison Wesley Longman.

Guthered, Tim.1996. The Study of Second Language Acquisition. Oxford: Oxford University Press.

Harmer, Jeremy. 2001. The Practice of English Language Teaching. Great Britain: Pearson Education Limited.

Underhill, M. 1987. Principles of Language Learning and Teaching. New York: Addison Wesley Longman.

Swan. 1980. Writing English Language Tests. London: Longman. 
